\title{
FUNCTIONAL TRAITS IN THE ARBOREAL COMPONENT OF THE CERRADO VEGETABLE COMMUNITY
}

\author{
Vagner Santiago do Vale ${ }^{1 *}$, Thales Alves Tormim da Veiga ${ }^{2}$, Jamir Afonso do Prado Júnior ${ }^{3}$, Lilian Cristina da \\ Silva Santos ${ }^{4}$, Jovan Martins Rios ${ }^{5}$, João Paulo Costa ${ }^{6}$ \\ ${ }^{1 *}$ State University of Goiás, Department of Forestry Engineering and Graduate Program in Plant Production, Ipameri, Goiás, Brazil - e-mail: \\ vsvale@ hotmail.com \\ ${ }^{12}$ State University of Goiás, Graduate Program in Plant Production, Ipameri, Goiás, Brazil - e-mail: thales_tormim@hotmail.com \\ ${ }^{3}$ Federal University of Uberlândia, Graduate Program in Ecology and Conservation of Natural Resources, Uberlândia, Minas Gerais, Brazil - \\ jamirjunior@yahoo.com.br \\ ${ }^{4}$ State University of Goiás, Graduate Program in Plant Production, Ipameri, Goiás, Brazil - e-mail: liliancristina 2011@ @otmail.com \\ ${ }^{5}$ Federal University of Goiás, Graduate Program in Agronomy, Goiânia, Goiás, Brasil - e-mail: jovan.jmr@ @mail.com \\ ${ }^{6}$ Federal University of Uberlândia, Graduate Program in Ecology and Conservation of Natural Resources, Uberlândia, Minas Gerais, Brazil - \\ joaopaulo_mc@hotmail.com
}

Received for publication: 12/02/2019 - Accepted for publication: 08/12/2020

\begin{abstract}
Resumo
Traços funcionais no componente arbóreo de comunidade vegetal de cerrado. O presente estudo teve como objetivo descrever atributos funcionais de espécies arbóreas em fragmentos de áreas de cerrado sensu stricto com transição para cerradão no município de Ipameri - GO, com o propósito de descrever quais atributos são mais representativos nessas fitofisionomias. Foram amostrados 10 indivíduos para cara uma das 20 espécies arbóreas mais comumente encontradas na região. Foram coletados traços funcionais relativos à arquitetura da parte aérea da árvore e traços funcionais foliares. Com os traços funcionais avaliados foi realizada uma análise de variância e teste a posteriori de Tukey a $0,5 \%$, em seguida os dados foram padronizados e as espécies foram funcionalmente agrupadas. Os resultados demonstraram grande variabilidade dos traços funcionais com a formação de dois grupos de espécies com características semelhantes, o grupo 1 foi formado por espécies com traços funcionais próprios à sobrevivência em condições adversas do ambiente, como solos pobres, sazonalidade e incidentes naturais ou provocados, como o fogo. Já o grupo 2, aparentemente aponta para traços funcionais relacionados ao sucesso e investimento no crescimento em altura, bem como para maior capacidade fotossintética e adaptações à condições de sombreamento. Os traços funcionais estudados indicaram a ocorrência de grande diversidade de adaptações entre as espécies, sendo possível dizer que ambos os grupos de espécies são importantes para a manutenção destas fitofisionomias na paisagem.

Palavras chave: Atributos Funcionais; Grupos Funcionais, Cerrados; Adaptações.
\end{abstract}

\begin{abstract}
The current study aimed to describe functional attributes of arboreal species in fragments of sensu stricto Cerrado areas with a transition to Cerradão in Ipameri - GO to describe which characteristics are more representative in these phytophysiognomies. Ten individuals were sampled for each of the twenty arboreous species most commonly found in the region. Functional attributes related to the architecture of the aerial part of the tree and functional leaf traits were collected. Once the functional traits were evaluated, an analysis of variance and a posterior Tukey test at $0.5 \%$ were performed. Then, the data were standardized, and the species were functionally grouped. The results showed great variability of the functional characteristics forming two groups of species with similar characteristics. Group 1 was constituted by species with functional traits proper to survival in adverse environmental conditions, such as poor soils, seasonality, and natural or provoked incidents, like fire. Group 2, on the other hand, apparently points to functional traits related to success and investment in height growth, as well as greater photosynthetic capacity and adaptations to shading conditions. The functional traits studied indicated the occurrence of a great diversity of adaptations between species. Therefore, it is possible to say that both groups of species are important for maintaining these phytophysiognomies in the landscape.

Keywords: Functional Attributes; Functional Groups, Cerrados; Adaptations.
\end{abstract}

\section{INTRODUCTION}

Functional traits are morphological, biochemical, or structural characteristics existing in an organism capable of interfering with its development and survival in a given environment (BRUELHEIDE et al., 2018). Studies focused on functional traits have become increasingly recurrent in recent years; however, there is still an impasse in the correct conception of which traits can be considered functional traits (BRUELHEIDE et al., 2018). In plants, the functional traits associated with individual growth and establishment are useful for understanding the species roles in different environmental conditions. For a good representation of these roles, it is necessary choosing traits that represent important functions performed by the species (VALE et al., 2011).

FLORESTA, Curitiba, PR, v. 51, n. 2, p. 311-319, abril/jun 2021.

Vale, V. S. et.al.

ISSN eletrônico 1982-4688

DOI: $10.5380 /$ rf.v51 i2. 64909 
Functional traits serve as important tools for studies considering environmental disturbances in certain tree communities (VALE et al., 2017). The variation of the functional traits in certain communities can explain the environmental or ecophysiological characteristics to which certain species had to adapt to be successful in certain situations (PÉREZ-HARGUINDEGUY et al., 2013). For the savanna plant formations present in the Cerrado, attributes providing survival in environments exposed to wind, susceptible to fire, seasonally dry climate, low fertility soil and $\mathrm{pH}$, and high mineral concentration often toxic to living cells, are important in species role understanding the in these environments (VALE et al., 2017).

The height and diameter of trees provide information on the total biomass and, consequently, the carbon stock present in the organism (THOMSON et al., 2011). Taller trees tend to have no light restrictions and can spread their propagules over long distances taking advantage of the action of winds in dry periods. Among the possible parameters to be evaluated, the bark thickness and the height at which the tree starts its branching in trunks (here called 1st branch) are extremely relevant traits to the aerial structure's survival after firing events (COSTA, 2019). The thicker the bark, the greater the internal tissue protection, and the farther the first branch is from the ground, the greater the crown's chances to escape the damage caused by fire (COSTA, 2019).

In turn, the area and the crown volume are also important traits of the trees' regenerative processes, with larger crowns providing greater shading, facilitating certain species occurrence, especially those with slow growth and larger size, also with more wide crowns (ARANTES et al., 2014). Simultaneously, they increase the tree biomass and photosynthetic capacity to provide a competitive advantage in growth. Finally, the functional traits related to leaves play a role in carbon absorption via photosynthesis and water loss through transpiration (GÁLVEZ; PEARCY, 2003).

Studies with functional traits in the Cerrado Biome are still scarce, and much of the knowledge about functional traits are focused on humid tropical forests (e.g., POORTER; BONGERS, 2006; CHAZDON et al., 2010) or for semideciduous seasonal forests (e.g., VALE et al., 2010; VALE et al., 2013; PRADO-JÚNIOR et al., 2016). Due to the trees species functional attributes analyses' importance to understand the existing patterns in the Cerrado and the lack of data on this topic, the present study aimed to i) describe the functional traits of tree species from the Cerrado; and ii) functionally group them to ascertain the existence of species with similar behaviors in the landscape. Especially in anthropized environments with a high frequency of fires, understanding which species have the greatest capacity to survive the weather should make it easier to understand these communities' future. We hope that the chosen functional traits will be enough to denote different functional groups associated with different ecological strategies.

\section{MATERIAL AND METHODS}

\section{Study areas}

Field data collection took place in different areas of the Cerrado remnants, restricted to the transition to cerradão in the southeastern region of Goias State, and anthropized areas were chosen due to agricultural management and eventual occurrence of fires.

\section{Species selection and pattern of individuals}

Field procedures were standardized following data collection protocols on functional traits (PÉREZHARGUINDEGUY et al., 2013). For the functional traits to be measured, the individual should be an adult, showing no signs of damage in the trunk such as termites or rot, fully expanded leaves, without damage by phytopathological diseases such as fungi and galls that would impair the subsequent analysis of any trait. Twenty arboreal species with wide occurrence in the Cerrado domain and/or in the southeastern region of Goias were chosen (LOPES et al., 2011, RIOS et al., 2020), especially in Ipameri, Catalão, and Caldas Novas. According to Rios et al. 2020, these species comprise about $75 \%$ of importance in the region. This value was based on the density, frequency, and relative dominance of these species in areas in Ipameri, where most of the collections occurred. Each species had between 9-10 individuals sampled. Of these species, only the functional traits that denote clear ecosystem functions and/or ability to survive and resist the environment were selected (Table 1).

FLORESTA, Curitiba, PR, v. 51, n. 2, p. 311-319, abril/jun 2021.

Vale, V. S. et.al. 
Table 1. Functional traits studied and their functionality within ecosystems.

Tabela 1. Traços funcionais estudados e sua funcionalidade dentro dos ecossistemas.

\begin{tabular}{|c|c|c|c|}
\hline Functional trait & Unit & Ecological and physiological functions & References \\
\hline Tree height & $\mathrm{m}$ & $\begin{array}{l}\text { Carbon storage, competition for light, seed } \\
\text { dispersal. }\end{array}$ & $\begin{array}{l}\text { Thomson et al. } \\
\text { (2011). }\end{array}$ \\
\hline Circunference at $0,30 \mathrm{~m}$ & $\mathrm{~m}$ & Carbon storage. & Missio et al. (2017). \\
\hline Bark thickness & $\mathrm{mm}$ & Protection against abiotic factors. & $\begin{array}{l}\text { Hoffmann et al. } \\
\text { (2009). }\end{array}$ \\
\hline $1^{\circ}$ branch height & $\mathrm{m}$ & \multirow{4}{*}{$\begin{array}{c}\text { Competition for light, photosynthetic } \\
\text { capacity, carbon storage, understory } \\
\text { shading. }\end{array}$} & \multirow{4}{*}{$\begin{array}{l}\text { Poorter; Bongers. } \\
\text { (2006). }\end{array}$} \\
\hline Crown área & $\mathrm{m}^{2}$ & & \\
\hline Crown volume & $\mathrm{m}^{3}$ & & \\
\hline Leaf fresh matter & $\mathrm{mg}$ & & \\
\hline Leaf dry matter & $\mathrm{mg}$ & \multirow{3}{*}{$\begin{array}{l}\text { Photosynthetic capacity and efficiency, } \\
\text { carbon incorporation, competition for light, } \\
\text { relative growth rate. }\end{array}$} & \multirow{3}{*}{$\begin{array}{l}\text { Prado-Junior et al. } \\
\qquad 2015\end{array}$} \\
\hline Leaf área & $\mathrm{mm}^{2}$ & & \\
\hline Specific leaf area & $\mathrm{mm}^{2} / \mathrm{mg}$ & & \\
\hline
\end{tabular}

\section{Data collections}

For each species individual sampled in the field, ten leaves were collected for analysis of leaf traits. Only individuals with a circumference equal to or greater than $15 \mathrm{~cm}$ at the height of $0.30 \mathrm{~m}$ from the ground level were sampled since they were considered adult individuals. The samples (leaves attached to the branches) were packaged in closed plastic bags to avoid excessive moisture loss, with samples being preferably gathered during the first hours of the day, usually from 6:00 am to 8:00 am. Later, the leaves were analyzed in the laboratory.

\section{Functional traits}

The fresh matter (FM) was quantified with a precision scale, and then the leaves were scanned with a scanner at a resolution of $100 \mathrm{dpi}$. At the end of digitization, the leaves were individually wrapped in paper bags and placed in an oven at $70^{\circ} \mathrm{C}$ for 72 hours for moisture loss. Their mass was quantified using a precision scale to obtain the dry matter (DM). The digitalized images of leaves were analyzed using the Image $\mathrm{J}$ software (Schneider et al., 2012) to obtain the leaf area (LA). At the same time, the specific leaf area (SLA) was obtained by calculating the ratio between LA $\left(\mathrm{mm}^{2}\right) /$ dry matter $(\mathrm{DM})(\mathrm{mg})$.

The same individuals who had their leaf traits collected also underwent evaluation of non-leaf traits. The circumference was measured at $0.30 \mathrm{~m}$ high (C30) using a measuring tape (this was converted into a diameter for the following calculations). In turn, the height of the first branch (1st Bran) and the individual's total height (Ht) were obtained using a $4.0 \mathrm{~m}$ graduated ruler. For larger trees, a Haglof clinometer was used. The bark's thickness was measured with the collection of a small sample at $0.30 \mathrm{~m}$ above the ground and then measured using a caliper in the greatest visual thickness. The crown area projected onto the ground (CA) was calculated based on the largest crown diameter and the diameter perpendicular to it using a measuring tape. The CA was calculated using the formula:

$$
\mathrm{AC}=0.25 \pi \cdot \mathrm{d} 1 . \mathrm{d} 2
$$

Where $\mathrm{d} 1$ and $\mathrm{d} 2$ are the crown diameters measured in both directions (POORTER; BONGERS, 2006). The crown volume $(\mathrm{CV})$ was also measured, estimating from the ellipse volume formula:

$$
\mathrm{VC}=\frac{4 \cdot \pi \cdot \mathrm{a} 2 \cdot \mathrm{b} 2 \cdot \mathrm{c} 2}{3 \cdot 2}
$$

Where $\mathrm{a} 2$ is the largest crown radius, b2 is the smallest crown radius, and $\mathrm{c} 2$ is the crown size, which is the distance between the total height $(\mathrm{Ht})$ and the first branch height (1st Bran). The formula was based on mathematical formulas for calculating the volume of irregular spheres.

Analysis of variance between species was performed using the STATISTICA software, and then the Tukey test at $0.5 \%$. The species and all functional traits were analyzed utilizing the principal components analysis to verify the functional traits that best denote species differences. Before this procedure, variables with high correlation with each other (greater than 0.9 for the Pearson correlation) were removed from the analysis. In this

FLORESTA, Curitiba, PR, v. 51, n. 2, p. 311-319, abril/jun 2021.

Vale, V. S. et.al. 
case, the variable CA was removed due to its high correlation with CV. After this procedure, the data were normalized between 0 and 1 using the minimum and maximum formula (PATRO; SAHU, 2015):

$$
\text { Normalizing trait }=\left(\frac{\text { minimum trait }}{\text { maximum }- \text { minimum }}\right)
$$

Similarity analysis was then run using the Euclidean distance, and a similarity dendrogram was formed by Ward's grouping method. The purpose of this analysis was the formation of species groups with similar traits/functions. Therefore, a discriminant analysis was performed to confirm the groups. This statistical technique is used to classify elements of a sample which confirms or not whether that element actually belongs to that group (LATTIN et al., 2011). In our case, it confirms or not whether the species was correctly allocated to the group proposed by the dendrogram.

\section{RESULTS}

Functional traits of the tree architecture, ANOVA results, and Tukey test

The results show that there is an evident variation in functional attributes between the species studied. The mean height values ranged significantly between $1.41 \mathrm{~m}$ for Himatanthus obovatus (Müll.Arg.) Woodson and $11.70 \mathrm{~m}$ for Emmotum nitens (Benth.) Miers (F19.177 = 17.2, p <0.001), showing the occurrence of a continuum of heights among the studied species. Emmotum nitens (Benth.) Miers stood out for having an average height above all others. For $\mathrm{C} 30$, the results point again to the extremes between the species $H$. obovatus with the lowest average and $E$. nitens with the highest average, $0.18 \mathrm{~m}$ and $0.48 \mathrm{~m}$, respectively. The ANOVA results for C30 were significant $(\mathrm{F} 19.177=14.18, \mathrm{p}<0.001)$, while the Tukey test determined that $E$. nitens has the largest circumference at $0.30 \mathrm{~m}$ compared to the other species (Table 2 ). The average bark thickness values were between $0.02 \mathrm{~mm}$ for the species Annona coriacea Mart. and $1.99 \mathrm{~mm}$ for Diospyros burchellii Hiern, with significant ANOVA $(\mathrm{F} 19.177=16.03, \mathrm{p}<0.001)$ with the Tukey test showing a great variation between species of a greater and lesser bark thickness.

As for the height in meters of the 1st branch, the species E. nitens had the highest average, $1.44 \mathrm{~m}$ but still similar to most species $(\mathrm{F} 19.177=2.36, \mathrm{p}<0.001)$. For the crown area $\left(\mathrm{m}^{2}\right)$, the species $E$. nitens presented the highest average, $76.68 \mathrm{~m}^{2}$, being Terminalia argentea Mart. the second higher average, $36.66 \mathrm{~m}^{2}$. ANOVA was also significant for this trait presenting $(\mathrm{F} 19.177=21.35, \mathrm{p}<0.001)$. For the crown volume $\left(\mathrm{m}^{3}\right)$, E. nitens presented the highest average of $2,178.64 \mathrm{~m}^{3}$. However, little significant variation was observed between the species studied $(\mathrm{F} 19.177=24.52, \mathrm{p}<0.001)$. According to the Tukey test carried out, it was possible to observe that, except for E. nitens, the other species were similar to each other, with the Kielmeyera coriacea Mart. species have the lowest average crown volume, with $1.49 \mathrm{~m}^{3}$.

\section{Functional leaf traits, ANOVA results, and Tukey test}

The functional leaf traits showed evident variation between the studied species. The average values for FM varied from $333.6 \mathrm{mg}$ (Myrcia splendens (Sw.) DC.) to $6069.7 \mathrm{mg}$ (D. burchellii). The analysis of variance of this leaf trait showed significant differences (F19.183 = 37.038; $<$ <.001) between the species studied (Table 3). The average values for DM ranged from $142.2 \mathrm{mg}$ for $M$. splendens to $2742.7 \mathrm{mg}$ for $D$. burchellii. This leaf trait analysis of variance showed significant differences between the studied species $(F 19,183=25,223 ; p<0,001)$.

Table 2. Average values, standard deviation in bracket and Tukey test (superscript letters) for tree architecture traits. The averages followed by the same letter in the column do not differ by Tukey test $<0.05 \%$.

Tabela 2. Média, desvio padrão (entre parênteses) e teste Tukey (letras em sobrescrito) para traços de arquitetura da árvore. * As médias seguidas de mesma letra na coluna não diferem entre si pelo teste Tukey < $0,05 \%$.

\begin{tabular}{lrrrrrr}
\hline Species & $\begin{array}{c}\text { Tree Height } \\
(\mathbf{m})\end{array}$ & $\begin{array}{c}\text { Circunference } \\
(\mathbf{m})\end{array}$ & $\begin{array}{c}\text { Bark } \\
(\mathbf{m m})\end{array}$ & $\begin{array}{c}\mathbf{1}^{\circ} \text { Branch } \\
(\mathbf{m})\end{array}$ & $\begin{array}{c}\text { Can. Area } \\
\left(\mathbf{m}^{2}\right)\end{array}$ & $\begin{array}{c}\text { Can. Volume } \\
\left(\mathbf{m}^{3}\right)\end{array}$ \\
\hline A. coriacea & $3.29( \pm 0.76)^{\mathrm{efgh}}$ & $0.36( \pm 0.12)^{\mathrm{cde}}$ & $0.02( \pm 0.04)^{\mathrm{i}}$ & $0.92( \pm 0.45)^{\mathrm{ab}}$ & $3.82( \pm 1.40)^{\mathrm{c}}$ & $25.34( \pm 15.33)^{\mathrm{c}}$ \\
A. crassifolia & $3.43( \pm 1.17)^{\mathrm{defgh}}$ & $0.52( \pm 0.10)^{\mathrm{bcd}}$ & $0.75( \pm 0.60)^{\mathrm{bcdefgh}}$ & $1.02( \pm 0.61)^{\mathrm{ab}}$ & $8.23( \pm 4.00)^{\mathrm{c}}$ & $60.61( \pm 57.58)^{\mathrm{c}}$ \\
A. tomentosum & $6.85( \pm 1.51)^{\mathrm{bc}}$ & $0.69( \pm 0.12)^{\mathrm{b}}$ & $0.89( \pm 0.30)^{\mathrm{bcdef}}$ & $0.80( \pm 0.16)^{\mathrm{ab}}$ & $6.84( \pm 4.51)^{\mathrm{c}}$ & $120.71( \pm 109.01)^{\mathrm{c}}$ \\
C. brasiliense & $5.87( \pm 1.46)^{\mathrm{bcde}}$ & $0.55( \pm 0.13)^{\mathrm{bcd}}$ & $0.96( \pm 0.25)^{\mathrm{bcde}}$ & $1.11( \pm 0.59)^{\mathrm{ab}}$ & $13.36( \pm 3.88)^{\mathrm{c}}$ & $173.75( \pm 81.42)^{\mathrm{c}}$ \\
C. americana & $4.14( \pm 1.26)^{\mathrm{bcdefgh}}$ & $0.42( \pm 0.17)^{\mathrm{bcde}}$ & $0.93( \pm 0.37)^{\mathrm{bcdef}}$ & $0.90( \pm 0.47)^{\mathrm{ab}}$ & $4.89( \pm 5.39)^{\mathrm{c}}$ & $51.15( \pm 77.36)^{\mathrm{c}}$ \\
D. burchellii & $4.02( \pm 1.16)^{\mathrm{cdefgh}}$ & $0.57( \pm 0.16)^{\mathrm{bcd}}$ & $1.99( \pm 0.50)^{\mathrm{a}}$ & $1.29( \pm 1.27)^{\mathrm{ab}}$ & $8.11( \pm 5.59)^{\mathrm{c}}$ & $70.74( \pm 60.58)^{\mathrm{c}}$ \\
E. nitens & $11.7( \pm 1.82)^{\mathrm{a}}$ & $1.25( \pm 0.48)^{\mathrm{a}}$ & $1.18( \pm 0.85)^{\mathrm{b}}$ & $1.44\left( \pm 0.74^{\mathrm{a}}\right.$ & $76.68( \pm 37.56)^{\mathrm{a}}$ & $2178.64( \pm 1171.55)^{\mathrm{a}}$
\end{tabular}

FLORESTA, Curitiba, PR, v. 51, n. 2, p. 311-319, abril/jun 2021.

Vale, V. S. et.al. 


\begin{tabular}{|c|c|c|c|c|c|c|}
\hline H. stigonocarpa & $4.93( \pm 2.59)^{\mathrm{bcdef}}$ & $0.40( \pm 0.30)^{\mathrm{bcde}}$ & $0.21( \pm 0.38)^{\mathrm{hi}}$ & $0.93( \pm 0.55)^{\mathrm{ab}}$ & $13.08( \pm 18.45)^{\mathrm{c}}$ & $246.62( \pm 587.84)^{\mathrm{b}}$ \\
\hline H. obovatus & $1.41( \pm 0.52)^{\mathrm{h}}$ & $0.18( \pm 0.05)^{\mathrm{e}}$ & $0.18( \pm 0.21)^{\mathrm{hi}}$ & $0.70( \pm 0.29)^{\mathrm{ab}}$ & $0.92( \pm 1.54)^{\mathrm{c}}$ & $2.31( \pm 3.97)$ \\
\hline K. coriacea & $2.03( \pm 0.64)^{\mathrm{gh}}$ & $0.29( \pm 0.22)^{\mathrm{de}}$ & $0.72( \pm 0.30)^{\text {bcdefgh }}$ & $0.55( \pm 0.24)^{\mathrm{b}}$ & $0.44( \pm 0.46)^{\mathrm{c}}$ & $1.49( \pm 1.20)$ \\
\hline L. $p$ & $4.02( \pm 1.52)^{\text {cdefgh }}$ & $0.38( \pm 0.12)^{\text {bcde }}$ & $1.15( \pm 0.39)^{\mathrm{bc}}$ & $1.09( \pm 0.52)^{\mathrm{ab}}$ & $4.59( \pm 3.77)^{\mathrm{c}}$ & $46.79( \pm 54.25)$ \\
\hline M. guianensis & $5.26( \pm 1.19)^{\mathrm{bcde}}$ & $0.32( \pm 0.16)^{\text {bcde }}$ & $0.25( \pm 0.23)^{\mathrm{ghi}}$ & $1.29( \pm 0.71)^{\mathrm{ab}}$ & $6.01( \pm 4.10)^{\mathrm{c}}$ & $70.43( \pm 61.21)$ \\
\hline M. splendens & $4.94( \pm 1.00)^{\text {bcdef }}$ & $0.35( \pm 0.17)^{\text {cde }}$ & $0.43( \pm 0.30)^{\text {defghi }}$ & $0.79( \pm 0.40)^{\mathrm{ab}}$ & $8.89( \pm 8.79)^{\mathrm{c}}$ & $109.47( \pm 121.61)$ \\
\hline P. rotundifolia & $2.56( \pm 1.06)^{\mathrm{fgh}}$ & $0.34( \pm 0.07)^{\mathrm{de}}$ & $0.40( \pm 0.27)^{\text {efghi }}$ & $0.77( \pm 0.35)^{\mathrm{ab}}$ & $2.50( \pm 1.95)^{\mathrm{c}}$ & $16.24( \pm 20.14)$ \\
\hline P. populnea & $5.04( \pm 2.85)^{\mathrm{bcdef}}$ & $0.35( \pm 0.21)^{\text {cde }}$ & $0.38( \pm 0.19)^{\text {efghi }}$ & $1.28( \pm 0.61)^{\mathrm{ab}}$ & $9.18( \pm 10.81)^{\mathrm{c}}$ & $124.55( \pm 192.10)$ \\
\hline Q. grandiflora & $4.76( \pm 1.20)^{\mathrm{bcdefg}}$ & $0.45( \pm 0.05)^{\mathrm{bcde}}$ & $0.87( \pm 0.33)^{\mathrm{bcdefg}}$ & $0.94( \pm 0.28)^{\mathrm{ab}}$ & $5.99( \pm 2.99)^{\mathrm{c}}$ & $73.68( \pm 39.02)$ \\
\hline Q. parviflora & $6.57( \pm 3.01)^{\mathrm{bc}}$ & $0.54( \pm 0.20)^{\mathrm{bcd}}$ & $0.99( \pm 0.32)^{\mathrm{bcd}}$ & $0.54\left( \pm 0.34^{\mathrm{b}}\right.$ & $14.74( \pm 10.72)^{\mathrm{c}}$ & $259.64( \pm 235.13)^{\mathrm{b}}$ \\
\hline R. montana & $3.32( \pm 1.31)^{\mathrm{defgh}}$ & $0.34( \pm 0.14)^{\mathrm{de}}$ & $0.46( \pm 0.30)^{\mathrm{defghi}}$ & $1.23( \pm 0.50)^{\mathrm{ab}}$ & $3.67( \pm 3.46)^{\mathrm{c}}$ & $29.13( \pm 37.87)$ \\
\hline T. argentea & $6.97( \pm 2.59)^{\mathrm{b}}$ & $0.66( \pm 0.32)^{\mathrm{bc}}$ & $0.59( \pm 0.22)^{\text {cdefghi }}$ & $1.16( \pm 0.54)^{\mathrm{ab}}$ & $36.66( \pm 31.20)^{\mathrm{b}}$ & $724.36( \pm 738.54)$ \\
\hline$X$. aromatica & $6.18( \pm 1.99)^{\mathrm{bcd}}$ & $0.35( \pm 0.17)^{\mathrm{cde}}$ & $0.36( \pm 0.20)^{\mathrm{fghi}}$ & $1.12( \pm 0.62)^{\mathrm{ab}}$ & $16.33( \pm 12.58)^{\mathrm{c}}$ & $277.79( \pm 327.77)^{\mathrm{b}}$ \\
\hline
\end{tabular}

Table 3. Average values, standard deviation in bracket and Tukey test (superscript letters) of the foliar functional traits of the species analyzed and sampled in Cerrados located in three areas of Ipameri Goiás municipality. $\mathrm{MS}=$ dry mass; $\mathrm{AF}=$ leaf area; $\mathrm{AFE}=$ specific leaf area. * The averages followed by the same letter in the column do not differ by Tukey test $<0.05 \%$.

Tabela 3.Média, desvio padrão (entre parênteses) e teste Tukey (letras em sobrescrito) dos traços funcionais foliares das espécies analisadas e amostradas em Cerrados localizados em três áreas do município de Ipameri Goiás. $\mathrm{MF}=$ massa fresca; $\mathrm{MS}=$ massa seca; $\mathrm{AF}=$ área foliar; $\mathrm{AFE}=$ área foliar específica. * As médias seguidas de mesma letra na coluna não diferem entre si pelo teste Tukey $<0,05 \%$.

\begin{tabular}{|c|c|c|c|c|}
\hline Species & $\begin{array}{l}\text { MF } \\
(\mathrm{mg})\end{array}$ & $\begin{array}{l}\text { MS } \\
(\mathrm{mg})\end{array}$ & $\begin{array}{l}\mathbf{A F} \\
\left(\mathbf{m m}^{2}\right)\end{array}$ & $\begin{array}{l}\mathrm{AFE} \\
\left(\mathrm{mm}^{2} / \mathrm{mg}\right)\end{array}$ \\
\hline A. coriacea & $2621.2( \pm 673.1)^{\mathrm{cd}}$ & $754.5( \pm 227.1)^{\text {efghi }}$ & $6228.8( \pm 1595.5)^{\text {cdef }}$ & $9.1( \pm 2.3)^{\mathrm{abcdef}}$ \\
\hline A. crassifolia & $2361.6( \pm 310.2)^{\mathrm{cde}}$ & $769.3( \pm 79.9)^{\text {efghi }}$ & $7113.5( \pm 1687.3)^{\mathrm{cde}}$ & $9.3( \pm 1.6)^{\mathrm{abcde}}$ \\
\hline A. tomentosum & $3227.7( \pm 270.5)^{\mathrm{bc}}$ & $1287.9( \pm 215.3)^{\text {cde }}$ & $8984.9( \pm 2331.1)^{\mathrm{bc}}$ & $7.5( \pm 1.1)^{\mathrm{bcdefg}}$ \\
\hline C. brasiliense & $3124.0( \pm 639.9)^{\mathrm{bc}}$ & $503.9( \pm 133.0)^{\text {fghi }}$ & $8467.7( \pm 2010.6)^{\mathrm{bc}}$ & $5.9( \pm 1.1)^{\operatorname{defg}}$ \\
\hline C. americana & $2019.3( \pm 644.4)^{\text {cdef }}$ & $455.7( \pm 182.0)^{\mathrm{fghi}}$ & $6152.1( \pm 1777.1)^{\mathrm{cdf}}$ & $9.5( \pm 1.9)^{\mathrm{abcd}}$ \\
\hline D.burchellii & $6069.7\left( \pm 1773.8^{\mathrm{a}}\right.$ & $2742.7( \pm 782.6)^{\mathrm{a}}$ & $13648.7( \pm 3073.9)^{\mathrm{a}}$ & $5.2( \pm 0.6)^{\mathrm{gh}}$ \\
\hline E. nitens & $1506.2( \pm 373.0)^{\mathrm{defghi}}$ & $637.0( \pm 127.4)^{\mathrm{efghi}}$ & $5192.3( \pm 900.9)^{\operatorname{defg}}$ & $8.3( \pm 0.8)^{\mathrm{abcdefg}}$ \\
\hline H. stigonocarpa & $2012.2( \pm 1484.2)^{\mathrm{cdef}}$ & $2290.2( \pm 1283.4)^{\mathrm{ab}}$ & $4686.9( \pm 2803.8)^{\mathrm{efgh}}$ & $2.2( \pm 2.1)^{\mathrm{h}}$ \\
\hline H. obovatus & $5925.9( \pm 1581.7)^{\mathrm{a}}$ & $1337.0( \pm 433.7)^{\mathrm{bc}}$ & $11171.2( \pm 1732.2)^{\mathrm{ab}}$ & $6.6( \pm 1.0)^{\operatorname{cdefg}}$ \\
\hline K. coriacea & $3291.9( \pm 509.4)^{\mathrm{bc}}$ & $1097.4\left( \pm 218.4^{\text {cdef }}\right.$ & $6167.1( \pm 745.7)^{\mathrm{cdf}}$ & $6.5( \pm 2.3)^{\operatorname{cdefg}}$ \\
\hline L. pacari & $1547.8( \pm 442.8)^{\mathrm{defghi}}$ & $752.5( \pm 266.6)^{\mathrm{efghi}}$ & $4356.7( \pm 1029.3)^{\mathrm{efgh}}$ & $8.0( \pm 4.3)^{\mathrm{abcdefg}}$ \\
\hline M. guianensis & $582.6( \pm 174.5)^{\mathrm{hi}}$ & $262.7( \pm 65.1)^{\mathrm{hi}}$ & $2995.0( \pm 682.4)^{g h i}$ & $11.5( \pm 1.0)^{\mathrm{a}}$ \\
\hline M. splendens & $333.6( \pm 83.0)^{\mathrm{i}}$ & $142.2( \pm 43.1)^{\mathrm{i}}$ & $1435.5( \pm 329.7)^{\mathrm{i}}$ & $11.5( \pm 2.3)^{\mathrm{a}}$ \\
\hline P. rotundifolia & $1768.2( \pm 683.4)^{\mathrm{defgh}}$ & $872.7( \pm 349.5)^{\mathrm{defgh}}$ & $5323.4( \pm 1762.5)^{\operatorname{defg}}$ & $6.4( \pm 0.9)^{\operatorname{cdefg}}$ \\
\hline P. populnea & $990.3( \pm 272.4)^{\text {fghi }}$ & $368.3( \pm 120.3)^{\mathrm{ghi}}$ & $4034.6( \pm 1039.2)^{\mathrm{fghi}}$ & $11.6( \pm 1.5)^{\mathrm{a}}$ \\
\hline Q. grandiflora & $4206.7( \pm 1652.3)^{\mathrm{b}}$ & $1530.3\left( \pm 867.5^{\mathrm{cd}}\right.$ & $7669.2( \pm 3602.4)^{\mathrm{cd}}$ & $5.6( \pm 1.2)^{\mathrm{fgh}}$ \\
\hline$Q \cdot$ parviflora & $626.4( \pm 194.9)^{\mathrm{ghi}}$ & $222.4( \pm 72.2)^{\mathrm{hi}}$ & $2152.1( \pm 343.4)^{\mathrm{hi}}$ & $11.2( \pm 3.4)^{\mathrm{ab}}$ \\
\hline R. montana & $1967.7( \pm 712.9)^{\mathrm{cdefg}}$ & $1004.1( \pm 309.6)^{\operatorname{defg}}$ & $5005.6( \pm 1301.7)^{\mathrm{defgh}}$ & $5.7( \pm 1.3)^{\mathrm{efg}}$ \\
\hline T. argentea & $1203.5( \pm 500.2)^{\mathrm{efghi}}$ & $491.0( \pm 171.6)^{\mathrm{fghi}}$ & $4360.0( \pm 1920.1)^{\mathrm{efgh}}$ & $10.0( \pm 5.0)^{\mathrm{abc}}$ \\
\hline$X$. aromatica & $808.7( \pm 291.6)^{\mathrm{fghi}}$ & $329.5( \pm 105.6)^{\mathrm{ghi}}$ & $2977.4( \pm 804.1)^{\mathrm{ghi}}$ & $10.7( \pm 4.0)^{\mathrm{ab}}$ \\
\hline
\end{tabular}

FLORESTA, Curitiba, PR, v. 51, n. 2, p. 311-319, abril/jun 2021.

Vale, V. S. et.al. 
The mean values for LA ranged from $1435.5 \mathrm{~mm}^{2}$ in $M$. splendens to $13648.7 \mathrm{~mm}^{2}$ in D. burchellii. Analysis of variance of this leaf trait showed significant differences between species (F19.183 = 27.73; $\mathrm{p}<0.001)$. The averages for specific leaf area of species ranged from $11.6 \mathrm{~mm} / \mathrm{mg}$ in Plenckia populnea Reissek to 2.2 $\mathrm{mm}^{2} / \mathrm{mg}$ in $H$. stigonocarpa. The analysis of variance of the SFM $\left(\mathrm{mm}^{2} / \mathrm{mg}\right)$ presented results $(\mathrm{F}=19.183=$ 13.096; $\mathrm{p}<0.000$ ) where the values showed less variation among the other leaf traits.

The principal component analysis explained 74\% of the data variation on axes 1 and 2 (Figure 1). The leaf traits FM, DM, LA (positively), and SLA (negatively) showed the highest correlations with axis 1 (Table 4). In contrast, the traits of architecture $\mathrm{Ht}, \mathrm{C} 30$, Bark, $1^{\circ}$ Bran, and CV were correlated (all positively) with axis 2.

Table 4. Correlation values of the functional traits with the axes of the principal component analysis.

Tabela 4. Valores de correlação dos traços funcionais com os eixos da análise de componentes principais.

\begin{tabular}{lrr}
\hline & PC 1 & PC 2 \\
\hline Fresh matter (FM) $-\mathrm{mg}$ & 0.52458 & 0.07990 \\
Dry matter (DM) $-\mathrm{mg}$ & 0.48169 & 0.12415 \\
Leaf area (LA) $-\mathrm{mm}^{2}$ & 0.42642 & 0.16107 \\
Specific leaf area (SLA) $-\mathrm{mm} 2 / \mathrm{mg}$ & -0.43527 & -0.10389 \\
Tree height $-\mathrm{m}$ & -0.22291 & 0.41172 \\
Circunference $\left(\mathrm{C}_{30}\right)-\mathrm{cm}$ & -0.08427 & 0.46602 \\
Bark $-\mathrm{mm}$ & 0.13937 & 0.36169 \\
$1^{\circ}$ Bran $-\mathrm{m}$ & -0.11743 & 0.47246 \\
Crown volume $-\mathrm{m}^{3}$ & -0.17745 & 0.44804 \\
\hline
\end{tabular}

\section{Similarity of functional traits and cluster analysis}

The cluster analysis formed two distinct groups (Figure 2) of species based on the values of the functional leaf traits listed in Table 3. Group 1 was formed by the species: C. brasiliense, A. tomentosum, $Q$. grandiflora, $K$. coriacea, P. rotundifolia, L. pacari, $R$. montana, A. coriacea, A. crassifólia, C. americana, H. stignocarpha, $H$. obovatus, and group 2 by E. nitens, $M$. splendens, $Q$. parviflora, M. guianensis, $P$. populnea, X. aromatica, and $T$. argentea. The discriminant analysis confirmed both groups without changes in species for other groups $(\mathrm{F}=4.52$, $\mathrm{p}=0.016$ ). Group 1 was formed by 13 species, which had the lowest height values, circumference at 0.30 meters, crown area, and lowest values of specific leaf area, dry matter, and fresh matter. In turn, group 2 was formed by seven species, which had more than five meters of height and lower values of fresh matter and high specific leaf area.

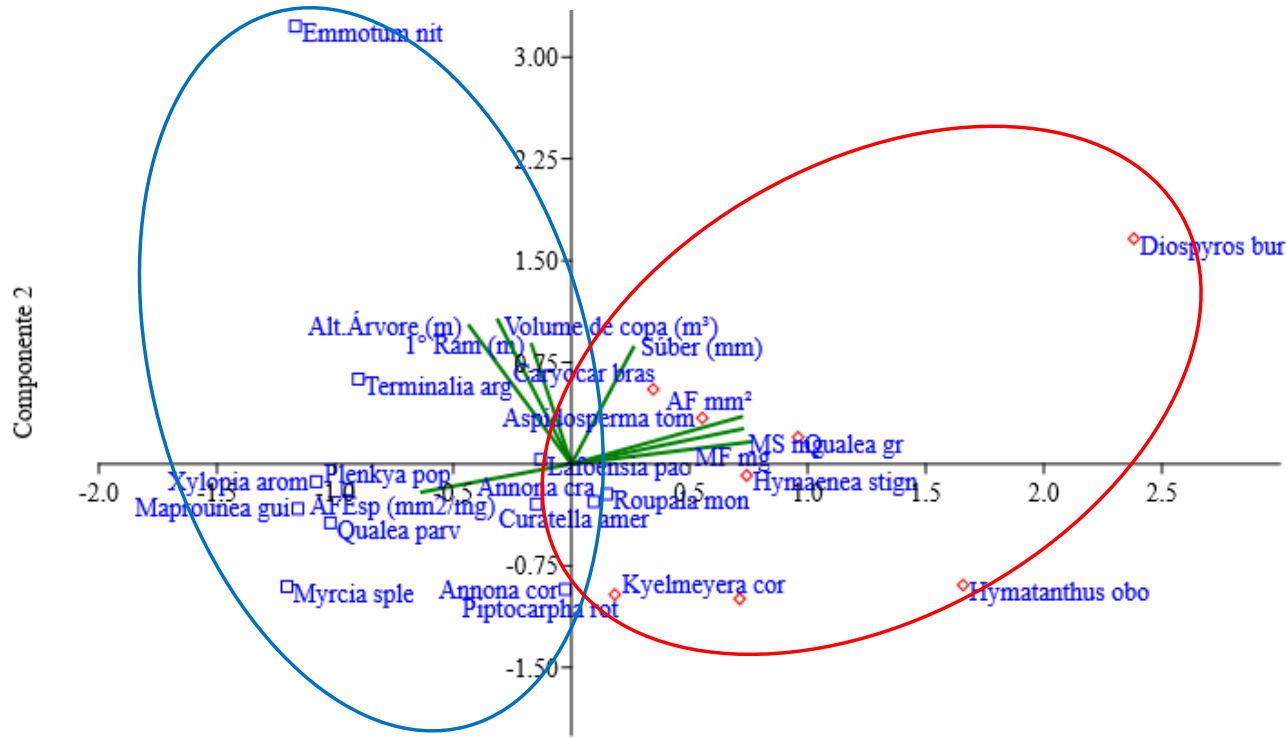

Componente 1

Figure 1. Principal component analysis for Cerrado species, using functional traits as variables.

Figura 1. Análise de componentes principais para espécies de cerrado, utilizando os traços funcionais como variáveis. 


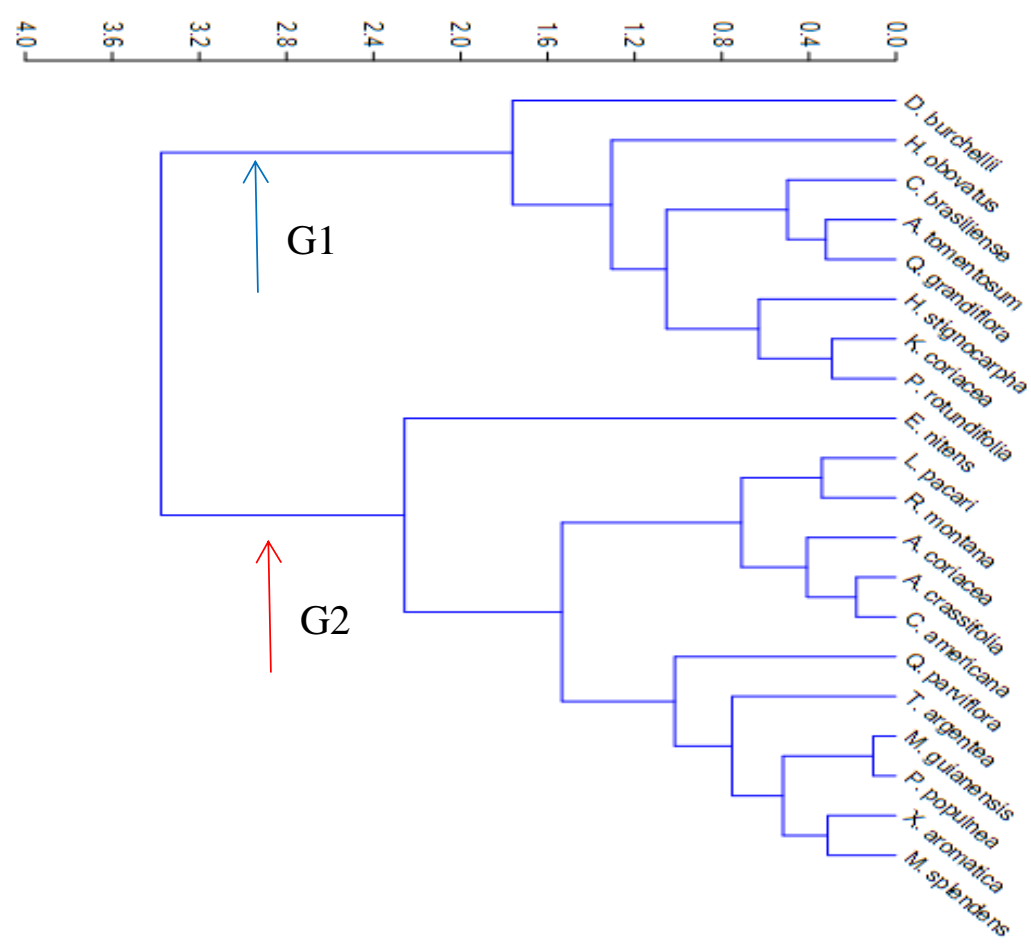

Figure 2. Cluster analysis results for the 20 species sampled in Cerrados located in three areas of Ipameri municipality, Goias. Simple Euclidean distance coefficient and Ward's cluster method (minimum variance).

Figura 2. Resultado da análise de agrupamento para as 20 espécies amostradas em Cerrados localizados em três áreas do município de Ipameri, Goiás. Coeficiente de distância euclidiana simples e o método de agrupamento de Ward (variância mínima).

\section{DISCUSSION}

\section{Functional traits of tree architecture}

The functional architectural traits of the crown were quite variable. Given the results obtained, it can be said that the Cerrados, although they are smaller vegetation compared to forests, are complex and diverse. $E$. nitens, T. argentea, A. tomentosum, Q. parviflora, and X. aromatica had the highest heights, above 6 meters on average. These species show competitive ability, especially in response to soil fire since above 3 meters of height, lethal damage to trees in the region where the study was carried out is quite small (HIGGINS et al. 2000). The higher the tree, the greater the chances of post-fire survival.

Within an environment in constant transformation caused by natural agents such as fire or anthropic ones such as savannah areas occupation for agriculture, the importance of resource allocation and adaptation of species must be emphasized. It is essential to pay attention to the ecosystem functional priorities as there is an environmental gradient within the studied area. Concerning this statement, it is evident that the measure that moves from the Cerrado stricto sensu to the Cerradão, the species tend to allocate more resources for certain types of functional traits, as observed in $E$. nitens, which invests more in the structure to acquire height, or for the species C. brasilliense, A. tomentosum, Q. grandiflora, K. coriacea, P. rotundifolia, L. pacari, R. montana, A. crassifolia, C. americana, and $H$. stignocarpha, which, although investing in height, also spend energy in architectural traits, such as the bark thickness.

The values obtained with the crown area and volume demonstrate the species' plasticity in adapting to different accesses to light, both horizontal and vertical, and is established according to the prevailing ecological conditions (VALLADARES; NIINEMETS, 2008).

\section{Leaf functional traits}

D.burchellii and H. obovatus were the species with the highest averages for fresh matter, which clearly explains their strategy for accumulating leaf biomass, especially because they are found in more open stricto sensu Cerrado areas, being more susceptible to suffer from anthropogenic and herbivory disturbances. For Poorter and Bongers (2006), species with superior DM can play strategies against herbivory and support physical damage more easily due to the robust and coarse structure of their leaves. 
The smallest FM species (M. splendens, M. guianensis) generally occur in more protected and inland areas in the study region. These species tend to compete for light and do not need a leaf apparatus resistant to water loss (WRIGHT et al., 2003).

According to Prado-Júnior et al. (2015), species with higher SLA express a response to shading. The species with the highest SLA as M. splendens, M. guianensis, and P. populnea were generally found in the sampled areas' understory. This functional trait was the most representative in terms of showing that the local community is selecting and adapting to environmental conditions.

\section{Principal component analysis and cluster analysis}

These analyses, taken together, were useful for demonstrating that the species respond differently considering the architectural and leaf traits. This difference shows that all traits (architecture and leaf) are important for understanding groups of species with similar community roles. Cluster analysis was essential to demonstrate the formation of functional groups of species with similar resource acquisition methods. According to Reich et al. (2003), in forest studies, the use of functional trait clusters is of relevant importance to establish the main functions of each species in its ecosystem. For the current study, even though this is in Cerrado areas, the species grouping based on their functional traits also enabled species classification according to their possible functions in the ecosystem.

It was evident the existence of a well-defined group of species with characteristics of typical cerrado, or stricto sensu, where tolerance to bad weather and mainly fires favor the development of shorter individuals with high regrowth power capable of tolerating longer drought periods. Such species also have deciduous over a long period of the year, a factor that also protects them from excessive water loss and the expense of allocating photoassimilates for new leaf growth (GIVNISH, 2002).

The species in the second group, on the other hand, have traits of a more forested environment, such as the phytophysiognomy known as "Cerradão", where the species development degree does not depend on extreme factors, such as a fire. When investing in growth, these species individuals have less need for protection against the foliage burning because the height itself acts as a protection against fire (HOFFMAN, 2009). Therefore this species group does not develop protection traits such as the bark thickness or more robust leaves as in the stricto sensu cerrado species. Cerrado species are less photosynthetically efficient than the others since they have a smaller specific leaf area. Still, they are more efficient in defending environmental weather conditions, and the transition of the two phytophysiognomies determines the function of each group (ROZENDAL et al., 2006).

\section{CONCLUSIONS}

- There was high variability in the functional traits between the studied species, making it possible to form two groups of species with different ecological strategies.

- The first group is associated with species that have a high ability to survive disturbances.

- The second group, in turn, is associated with the presence of species with high competitive capacity in forest environments.

\section{REFERENCES}

BRUELHEIDE, $\mathrm{H}$. et al. Global trait-environment relationships of plant communities. Nature Ecology \& Evolution, v.2, n.12, 1906-1917, 2018.

CHAZDON, R. L.; FINEGAN B.; CAPERS R.S.; SALGADO-NEGRET B.; CASANOVES F.; BOUKILI V. and NORDEN N. Composition and dynamics of functional groups of trees during tropical forest succession in Northeastern Costa Rica. Biotropica, v. 43, p. 31-40, 2010.

GIVNISH, T. J. Adaptive significance of evergreen vs. deciduous leaves: solving the triple paradox. Silva Fennica, Helsinki, v. 36, n. 3, p. 703-743, 2002.

HIGGINS, S. I.; BOND, W. J.; TROLLOPE, W.S.W. Fire, resprouting and variability, a recipe for grass-tree coexistence in savanna. Journal of Ecology, v.88, p. 213-229, 2000.

HOFFMANN, W. A. et al. Tree topkill, not mortality, governs the dynamics of savanna-forest boundaries under frequent fire in central Brazil. Ecology, [s.1.], v. 90, n. 5, p.1326-1337, maio 2009.

LATTIN, J. et al. Análise de Dados Multivariados. São Paulo: Cengage Learning, 2011.

LOPES, S. F. et al. Análise comparativa da estrutura e composição florística de cerrado no Brasil Central. Interciência, v. 36, n.1, p. 8 -15, 2011. 
MISSIO, F. F. et al. Atributos funcionais de espécies arbóreas em um fragmento de floresta ombrófila mista em Lages - SC. Ciência Florestal, [s.1.], v. 27, n. 1, p.215-224, 31 mar. 2017.

PÉREZ-HARGUINDEGUY, N. et al. New handbook for standardised measurement of plant functional traits worldwide. Australian Journal Of Botany, [s.1.], v. 61, n. 3, p.167-234, 2013.

POORTER, L.; BONGERS, F. Leaf traits are good predictors of plant performance across 53 rain forest species. Ecology, Ithaca, v. 87, n. 7, p.1733-1743, 2006.

PATRO, S. K. G.; SAHU, K. K. Normalization: A Preprocessing Stage. International Advanced Research Journal in Science, Engineering and Technology, v.. 2, n. 3, p. 20-22, 2015.

PRADO JÚNIOR, J. et al. Functional leaf traits of understory species: strategies to different disturbance severities. Brazilian Journal Of Biology, [s.1.], v. 75, n. 2, p.339-346, maio 2015.

PRADO-JUNIOR, J. A. et al. Conservative species drive biomass productivity in tropical dry forests. Journal Of Ecology, [s.1.], v. 104, n. 3, p.817-827, 19 fev. 2016.

REICH, P. B. et al. The evolution of plant functional variation: Traits, spectra, and strategies. International Journal of Plant Sciences, v. 164, p. 143-S164, 2003.

RIOS et al. Comparação de análises fitossociológicas e multivariadas na determinação do grau de conservação de áreas nativas de Cerrado. Ciência Florestal, v. 30, n. 3, p. 779-795, 2020.

ROZENDAL, D. M. A.; HURTADO, V. H; POORTER, L. Plasticity in leaf traits of 38 tropical tree species in response to light; relationships with light demand and adult stature. Functional Ecology, Oxford, v. 20, n. 2, p. 207-216, 2006.

SCHNEIDER, C. A.; RASBAND, W. S.; ELICEIRI, K. W. NIH Image to ImageJ: 25 years of image analysis. Nature methods, v. 9, n., p. 671-675, 2012

THOMSON, F. J. Seed dispersal distance in more strongly correlated with plant height than with seed mass. Journal of Ecology, Oxford, v. 99, n. 6, p. 1299-1307, 2011.

VALE, V.S.; DORNELES, M. C.; SCHIAVINI, I.; MENDONCA, E. T.; ALMEIDA, C. G.; CRESPILHO, R.F. Functional groups and its ecological importance in the wood vagetation in an urban remanescent forest, Uberlândia, MG. Natureza On Line, v. 9, p. 67-75, 2011.

VALE V. S.; SCHIAVINI, I.; OLIVEIRA A. P.; GUSSON A. E. When ecological functions are more important than richness: A conservation approach. Journal of Ecology and the Natural Environment 2: p. 270-280, 2010.

VALE, V. S.; SCHIAVINI, I.; LOPES, S. F.; OLIVEIRA, A. P.; DIAS NETO, O. C.; GUSSON, A. E. Functional groups in a semideciduous seasonal forest in Southeastern Brazil. Revista Biotemas, v.26, n.2, p.45-58, 2013.

VALE, V. S.; OLIVEIRA, A. P.; PRADO JUNIOR, J. A.; LONDE, P. R.; NASCIMENTO, D. R. Damming water influences the structure, composition and functions of adjacent savannahs. Madera y Bosques, vol. 23, n. 1, p. 63-77, 2017.

VALLADARES, F.; NIINEMETS U. Shade tolerance, a key plant feature of complex nature and consequences. Annual Review of Ecological and Systematics, v. 39, p. 237-257, 2008.

VIOLLE, C.; NAVAS, ML.; VILE D, KAZAKOU. E.; FORTUNEL, C.; HUMMEL, I. Let the concept of trait be functional! Oikos, v.116, p. 882-892, 2007.

WRIGHT, S. J.; H. C.; MULLER-LANDAU, R.; CONDIT, R.; HUBBELL, S. P. Gap-dependent recruitment, realized vital rates, and size distributions of tropical trees. Ecology. v.84, n. 3174-3185, 2003. 